\title{
Academic integrity and the implementation of the honour code in the clinical training of undergraduate dental students
}

Vidya Raman *i() and Shaun Ramlogan

\author{
* Correspondence: vidya.raman@sta. \\ uwi.edu \\ Periodontology, Restorative Unit, \\ School of Dentistry, the University \\ of the West Indies, Eric Williams \\ Medical Sciences Complex, St \\ Augustine, Uriah Butler Highway, \\ Champs Fleurs, Trinidad and \\ Tobago
}

\begin{abstract}
Educational pressures such as challenging workload, demanding deadlines and competitiveness among undergraduate dental students erode academic integrity in clinical training. The implementation of honour codes have been associated with the reduction in academic dishonesty.

An action research was undertaken to investigate and foster academic integrity through creative pedagogical strategies and the implementation of an honour code within the undergraduate dental programme.

Students reported the honour code as relevant (86.3\%) and it encouraged (>92\%) the five investigated fundamental values of academic integrity (International Centre of Academic Integrity). The students also favoured (86.3\%) the annual implementation of the honour code. The creative pedagogical strategy facilitated a change in perception on academic integrity in the clinical scenarios sessions. Most students (85.7\%) showed changes in perception of academic integrity. The majority of students' narratives/responses were positive and the emerging subthemes also espoused the five out of the six ICAI fundamental values of academic integrity. Students indicated the need for inclusion of academic integrity education within the curriculum. They felt that staff also should be guided by an academic integrity policy. Implementation of an honour code coupled with creative pedagogical strategies helped to foster understanding and appreciation for academic integrity. Conversely the honour code implementation was more effective due to the use of supportive creative pedagogical strategies on academic integrity. It is still undetermined whether these change in perception impacted on clinical practice during training and post-graduation.
\end{abstract}

Keywords: Action research, Academic integrity, Ethics, Honour code 


\section{Introduction}

\section{Academic integrity}

The International Centre of Academic Integrity (ICAI) defined academic integrity based on five fundamental values of 'honesty', 'trust', 'fairness', 'respect' and 'responsibility' with an updated inclusion of the sixth value of 'courage' as a quality element of commitment to the five original values, even in the face of adversity (Fishman 2014). Macfarlane (2014) have defined academic integrity as 'values, behaviour and conduct of academics in all aspects of their practice'. However, Bretag et al. (2013) have espoused that academic integrity should involve all stakeholders in learning and teaching inclusive of both academics (teachers) and students.

In medical academia, individuals must be committed to honesty and truthfulness in their pursuit of knowledge and such virtues are essential professional attributes for interaction with colleagues, peers, faculty, support staff and patients. Professionalism and ethics are moral qualities and characteristics which are an integral part of academic integrity. Dentistry is one health care profession which is guided by such a moral code of the Hippocratic oath.

Principles of behaviour and ethics for academic communities are governed by the ICAI fundamental values. Karp (2009) proposed that knowing ethics and being ethical were two different things; an individual has to know better in order to do better. Bertolami (2004) advocated self-introspection before ethical behaviour. An individual's action was dictated by internal reflection, one's value system, aspiration for oneself and influence of role models.

\section{Academic dishonesty}

Academic dishonesty was variably defined based on institution and country without universal consensus but may be simply referred to as fraud or cheating in an academic environment (Marshall and Varnon 2017). Academic dishonesty or cheating was not a new phenomenon and has become an increased problem among undergraduate students internationally (Martin et al. 2009, Elander et al. 2010, Thomas and De Bruin 2012). In a survey of 55 US dental schools (Beemsterboer et al. 2000), it was reported that academic dishonesty occurred in most schools with one to two incidences per year. Andrews et al. (2007) conducted an online study among dental students with students reporting to have cheated between $57.5 \%$ and $74 \%$ on assignments or exams respectively. Muhney et al. (2008) reported that $86.5 \%$ of graduating Texas dental hygiene students admitted to academic dishonesty at least once in their studies. Choi (2019) likewise reported cheating behaviour by students at $92.2 \%$ at the Korean dental school. While not limited to written examinations or assignments, cheating also has been cited in dental practical exams despite misconceptions of security and academic integrity for the latter (Currie et al. 2017).

Academic dishonesty included cheating (using unauthorized material or assistance), plagiarism (presenting someone's work as one's own without citing), fabrication (falsification of information), misrepresentation (example: false medical or excuse), collusion (group work for individual work), facilitation (assisting others in academic dishonesty) and contract cheating (outsourcing assessments to third parties) (Tatum and Schwartz 2017; Bretag et al. 2019). Studies have indicated that students engaged in academic 
dishonesty by various cheating behaviours (Rennie and Crosby 2001; Al-Dwairi and AlWaheidi 2004). The study by Al-Dwairi and Al-Waheidi identified thirteen categories of cheating behaviours among dental students. Some examples were forging faculty's signature, cheating in exams, changing clinical notes, plagiarism and writing proxy for friends. In a survey within Trinidad, West Indies at three tertiary institutions there were between $64.4 \%$ and $85.2 \%$ of students who recognized academic dishonesty among nine out of ten scenarios with high uncertainty for 'allowing student to copy my work' (25\%) and 'collaborative work for individual assignments' (50\%) (De Lisle et al. 2011). Prior student academic dishonesty has been linked to future unethical behaviour in the workplace. (Carpenter et al. 2004).

\section{Justifications for dishonesty}

Student justifications for academic dishonesty included: 'they cheated because others cheat', 'society was corrupt' and even 'teachers cheated when they were students' (Naghdipour and Emeagwali 2013). Other reasons for academic dishonesty were due to fear of failure, better grades, quick rewards, lack of time, lack of interest, lack of selfconfidence and embarrassment and appearance to others (Whitley and Keith-Spiegel 2002; Al-Dwairi and Al-Waheidi 2004). Institutional reasons for academic dishonesty related to large student enrolments, student diversities, increased technology application and multi-site virtual learning environments (De Lisle et al. 2011).

\section{Strategies to prevent academic dishonesty}

Hutton (2006) suggested strategies to prevent academic dishonesty by having universities address rules, policies and penalties during student orientation. Engler et al. (2008) concurred that institutions needed to create and foster a culture of academic integrity that supported the honour code and discouraged academic dishonesty. De Lisle et al. (2011) also suggested that strategies to curb academic integrity and ensure quality assurance in education included plagiarism detection software and an honour code. The honour code has been purported to shift the focus from the faculty to the student and aid in the accountability of the student (De Lisle et al. 2011).

\section{Honour code}

An honour code is a document that nurtures and refines moral behaviour in both social and academic settings (Gabbay 1999). Ideal components of an honour code pledge included formal language, consequences for cheating and requirement of signature (Gurung et al. 2012; Tatum and Schwartz 2017). However, students were more likely to cheat if there were punitive consequences for cheating (Miller et al. 2011). Gurung et al. (2012) suggested that optimization of the honour code would also include longer descriptive scripts as proposed prior to online examinations.

In an online survey of 61 US dental school, academic integrity strategies included an honour code (92\%), signed policy statement of compliance (92\%), a white coat ceremony (94\%) and first year orientation on expectations (96\%) (Graham et al. 2016). Many US universities have adopted honour codes since the 1900s but there were comparatively few universities in United Kingdom (UK) (Shepherd 2007; Forna 2012). In 2007, Northumbria University was one of the first UK universities to consider an 
honour code and loosely adopted an honour pledge (Forna 2012). Honour codes are uncommon within Trinidad and students were unfamiliar with this strategy (De Lisle et al. 2011). Similarly, within the commonwealth there appeared to be focus on education courses and policies on academic integrity or behaviour rather than an honour code (De Lisle et al. 2011; Spence 2015; University of Toronto 2019).

\section{Value of the honour code}

McCabe and Treviño (1993) conducted a study at 31 universities and colleges in the USA with and without honour codes. The study supported the implementation of the honour code as there was decreased cheating by $50 \%$ in universities with honour codes, even though $75 \%$ of the students admitted to participating in at least one form of dishonest behaviour. Other studies have also supported the implementation of an honour code with reported reduction in academic dishonesty (Melendez 1985: McCabe et al. 2002). Students from schools with 'Honor Codes' were also reported to have better understanding of dishonest behavior (Schwartz et al. 2013).

McCabe and Treviño (1993) also reported on five significant hypotheses in schools that had an honour code. Firstly, the students were reluctant to be dishonest with an honour code for fear of being caught. Secondly, the existence of an honour code assisted students understanding and acceptance of the school's policies regarding academic integrity. Thirdly, there was an inverse relationship of engaging in a dishonest act and being reported by a peer. The fourth hypothesis was that the perceived severity of the penalty for being dishonest actually deterred and reduced the number of incidents. Finally, the fifth hypothesis was that an honour code affected students' perceptions regarding the honest and ethical behaviour of their peers.

\section{Strategy for the honour code}

No doubt the honour code reduced academic dishonesty as it nurtured a culture of academic honesty and made students accountable both for their actions and their peer. McCabe and Treviño (1993) recommended that students must participate in the development and implementation of the honour code to be effective and that academic integrity must be a priority in the institution and must be communicated clearly to students. Involvement of students or collaborative work between staff and students was supported in developing guidelines and policies for enforcing academic integrity and the honour code inclusive of the clinical setting (Graham et al. 2016; Keener et al. 2019).

The honour code was dependent on the fact that the students were trusted to act honorably. However, honour codes by themselves did not bring about change and required discussions between students and staff and included expectations and consequences (Tatum and Schwartz 2017). Institutions needed to emphasize and nurture academic integrity (Tatum and Schwartz 2017). Student involvement measured through investment, commitment and satisfaction in the honour code significantly predicted the outcome of upholding of the honour code (Dix et al. 2014). Based on a review, tutorials inclusive of face to face and e-learning sessions were associated with improvements in knowledge and skill related to academic integrity (Stoesz and Yudintseva 2018). These 
authors further concluded that inclusion of hands-on training within these teaching sessions resulted in longer term benefits for the students.

\section{Creative pedagogy}

Berk (2001) and Whipp et al. (2000) indicated academic integrity should be incorporated into curriculum but it should be interactive and relationship-driven promoting introspection and self-knowledge by the students and instructors. Introspection and self-knowledge were critical components of emancipatory and practical knowledge (Whipp et al. 2000). It was through introspection, education, strong cultural and contextual factors that academic integrity was ingrained into students (McCabe et al. 2001).

In the study by Graham et al. (2016), 96\% of institutions included an orientation strategy on academic integrity expectations for first-year students. Others reported strategies included professional ethics programs and educational curriculum content. Thus there also was a pedagogical need to allow students to construct and create ideas within the classroom. A creative pedagogical approach was adopted which allowed the students to learn creatively with a creative goal rather than an acquisition of study material (Aleinikov 2013). Higher order educational components of critical thinking, problem solving and innovation have been linked with creativity and creative pedagogy which were relevant as twenty-first century skills and future post-graduation needs (Robinson et al. 2018). 'Praxis and environment' was the main emergent theme related to creative pedagogy in higher education and students viewed their 'own practices as most important to teaching, learning and creativity' (Robinson et al. 2018).

\section{Action research}

Action Research (AR) introduced by Kurt Lewin (1946) involved the research cycle framework for problem solving through (a) identification of the problem, (b) planned action, (c) implemented action and (d) assessment of the results of the action. Henson (1996) and Johnson (2012) added that action research was a systematic and orderly way for classroom teachers to observe their practice or to understand a problem and improve on the course of action. Sagor (2000) defined $\mathrm{AR}$ as a disciplined process of inquiry conducted by practitioners who wanted to improve their own situation. Action research was a collaborative process which promoted community effort (Sagor 2000).

A literature review of AR by Gibbs et al. (2017) highlighted that AR was a central theme in educational research and institutional change. The authors concluded that the literature supported improved teaching practice and student engagement. However, there was a need for critical and reflective practice with deep engagement while still maintaining the researcher objectivity. Action research has been successfully implemented in health care education (Ackerman et al. 2016; Erlam et al. 2018) including clinical clerkships (von Pressentin et al. 2016).

This action research (1) identified the problem of academic dishonesty, (2) planned intervention on academic integrity perceptions (3) executed action of an honour code and creative pedagogical strategies and (4) reviewed this action. 


\section{Aims and objectives}

The aim was to foster academic integrity via both creative pedagogical strategies and implementation of an honour code among undergraduate clinical dental students at the School of Dentistry, the University of the West Indies (UWI).

\section{Research questions}

\section{Main research questions}

1 Does the implementation of an honour code impact on perceptions of academic integrity among dental students prior to entry into clinic?

2 Do creative pedagogic strategies impact on the perceptions of academic integrity among dental students?

\section{Sub-questions}

3 What themes emerge as students engage in the creative pedagogical sessions on academic integrity?

4 What insights can be obtained from the study that can provide information on the creative pedagogical sessions for dental students?

\section{Methodology}

\section{Ethical consideration}

All classroom sessions were routine interactions as part of the undergraduate dental education. Students consented to participate in the questionnaires and classroom sessions without obligation or penalty. Ethical approval was not required from the Ethics Committee, The University of the West Indies as the activities related to teaching and learning within the undergraduate programme. However, approval was obtained from the Director of the School of Dentistry.

Consent was obtained from all students before administering the questionnaires. The questionnaires were anonymous and were part of an educational and institutional developmental initiative. It was emphasized that the interest of the study was student group averages to encourage honesty.

\section{Pre-study: identification of the problem Population}

The conceptual framework for this action research included fostering academic integrity and the implementation of the honour code. This framework is shown in the flow diagram of Fig. 1. The first stage of the study was to conduct a preliminary investigation and identify the problem. A pre-study questionnaire was conducted for all students in the School of Dentistry (SOD), the Faculty of Medical Sciences, The University of the West Indies, Trinidad comprising of 3rd, 4th and 5th year students. $(N=91$; Age: 20-34 years; Gender: $71 \%$ female and $29 \%$ male). 


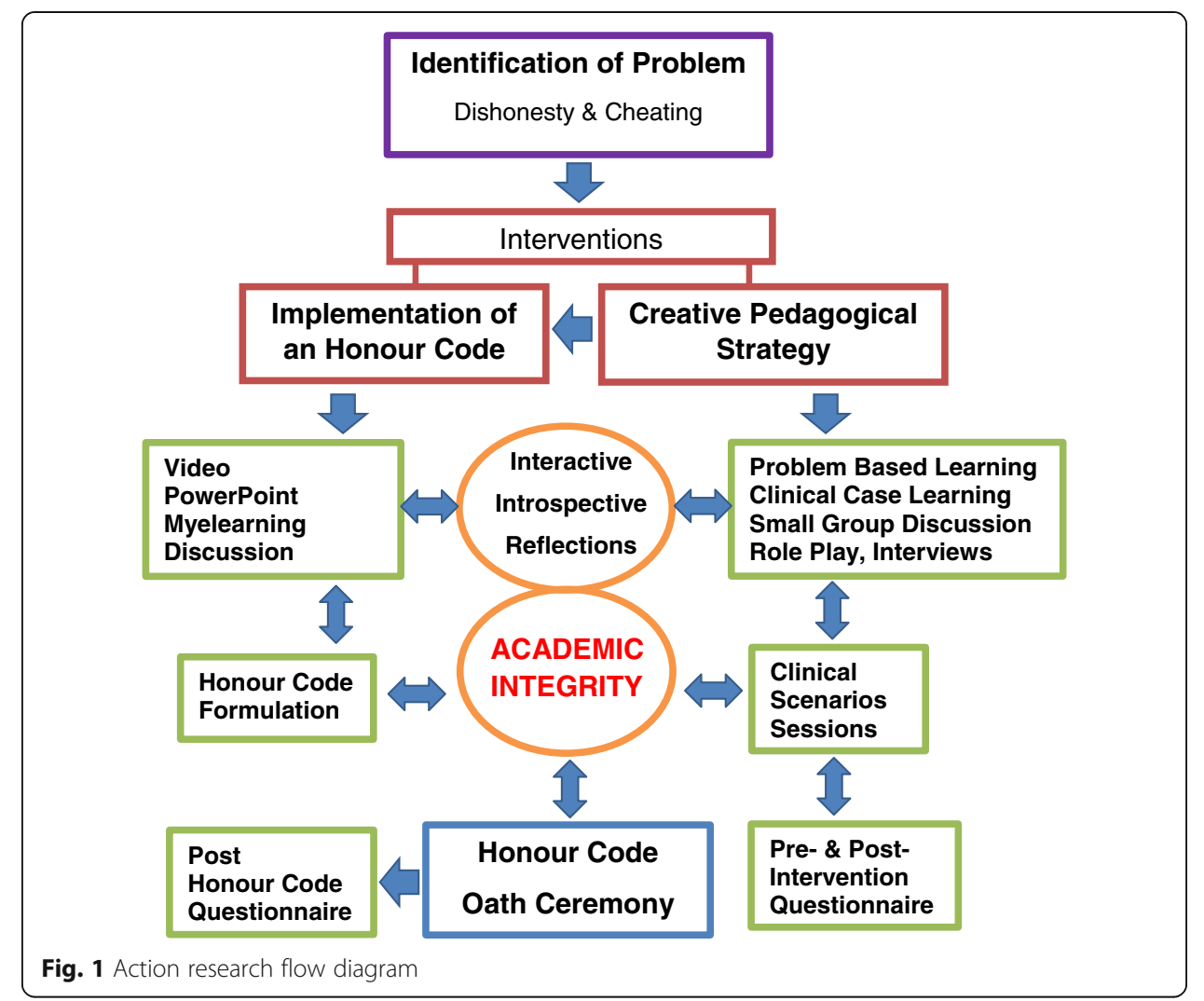

\section{Pre-study questionnaire}

The questionnaire comprised of one direct general question on presence of dishonesty in the school and the other questions on different scenarios of dishonestly in a non- clinical and clinical setting. These questions were derived from the literature and covered forged signatures, copying in a written exam, use of disallowed material, ghost writers, plagiarism and shared test for non-clinical scenarios (AlDwairi and Al-Waheidi 2004; Tatum and Schwartz 2017). Clinical scenario questions included falsification of clinical notes; discarding of clinical notes, unnecessary clinical procedures for quotas; cheating in a clinical exam and absenteeism due to false medical. The preliminary data analysis was to verify the problem of academic dishonesty and orient this problem in the context of student knowledge and awareness through group collaboration to elicit student perspectives and concerns. There was no attempt to validate the questionnaire as the intention was to simply verify dishonesty observed by lecturers at SOD.

\section{Collaborative analysis phase: determination of need for honour code}

The first plan of action was to introduce and stimulate discussion on the concept of academic integrity among the dental students. An open access 'YouTube' video on 'Academic Integrity' from the Humber College, School of Health Science (Humber College 2019) was presented to all students. This video was chosen as it was a simple media format on academic integrity which was established and tested at another institution. 
This was followed by student driven interactive discussion and debate on academic integrity. Steaming out of this collaborative session, the problem was further elucidated with an identified need for an honour code to support academic integrity. Subsequently two 'PowerPoint' presentations were delivered by the lecturers to share resources for understanding and development of an honour code.

\section{Post-study action plan: development of honour code and oath ceremony}

Creative pedagogical methods of critical thinking and problem solving were utilized in the student driven interactive session for the development of the honour code for the SOD. Building on their previous knowledge and research, students selected suitable elements and created the honour code. Students excluded components of penalties for transgression and concentrated on academic integrity in clinical setting. The importance of this process was to ensure that the students felt ownership for their own honour code rather than simply adopting a previously published example. Once the honour code was drafted, it was posted on the UWI's online Moodle platform, MyeLearning for reflection and feedback prior to finalization. The honour code is shown in Fig. 2. At the honour code oath ceremony, students took the oath and signed the honour code certificate before receiving their clinical badges and commencing clinical training.

Post-intervention of the honour code oath ceremony, questionnaires were distributed to early clinical years, 3rd and 4th year students. Questions included the relevance, implementation and the relation of the honour code to the five original fundamental values of academic integrity (Fig. 3).

\section{Parallel pedagogical strategy}

Creative pedagogic sessions utilizing student-run problem-based learning, clinical case learning, small group discussion, role play and interviews/questionnaires were strategies adopted to foster academic Integrity.

There were two clinical scenarios sessions; session I on record keeping, patient confidentiality and session II on case related ethical issues. The pre-intervention questionnaire was administered to determine baseline perceptions followed by discussion in both sessions I and II. After all pedagogical sessions and the honour code oath ceremony, the same questionnaire was re-administered to obtain post-intervention perceptions. The questionnaire was developed by both authors who were lecturers in periodontology attending to both pre-clinical and clinical years. The items covered common ethical clinical dilemmas and were drawn on the experience of the lecturers. There was not an attempt to standardize this questionnaire. The questionnaire for session I covered basic items of recordkeeping and confidentiality while session II questionnaire covered specific case related ethical dilemmas. Sample questions are shown in Fig. 4.

These sessions promoted active student participation, introspection, group problem solving, critical thinking and reflection. The learning outcomes were to: 1. Explain and resolve given ethical issues in theory and in practice. 2. Demonstrate a systematic approach to ethical reasoning and problem solving. The main objectives were to: 1 . Discuss and illustrate the importance of recognizing when an ethical dilemma appears. 2 . 


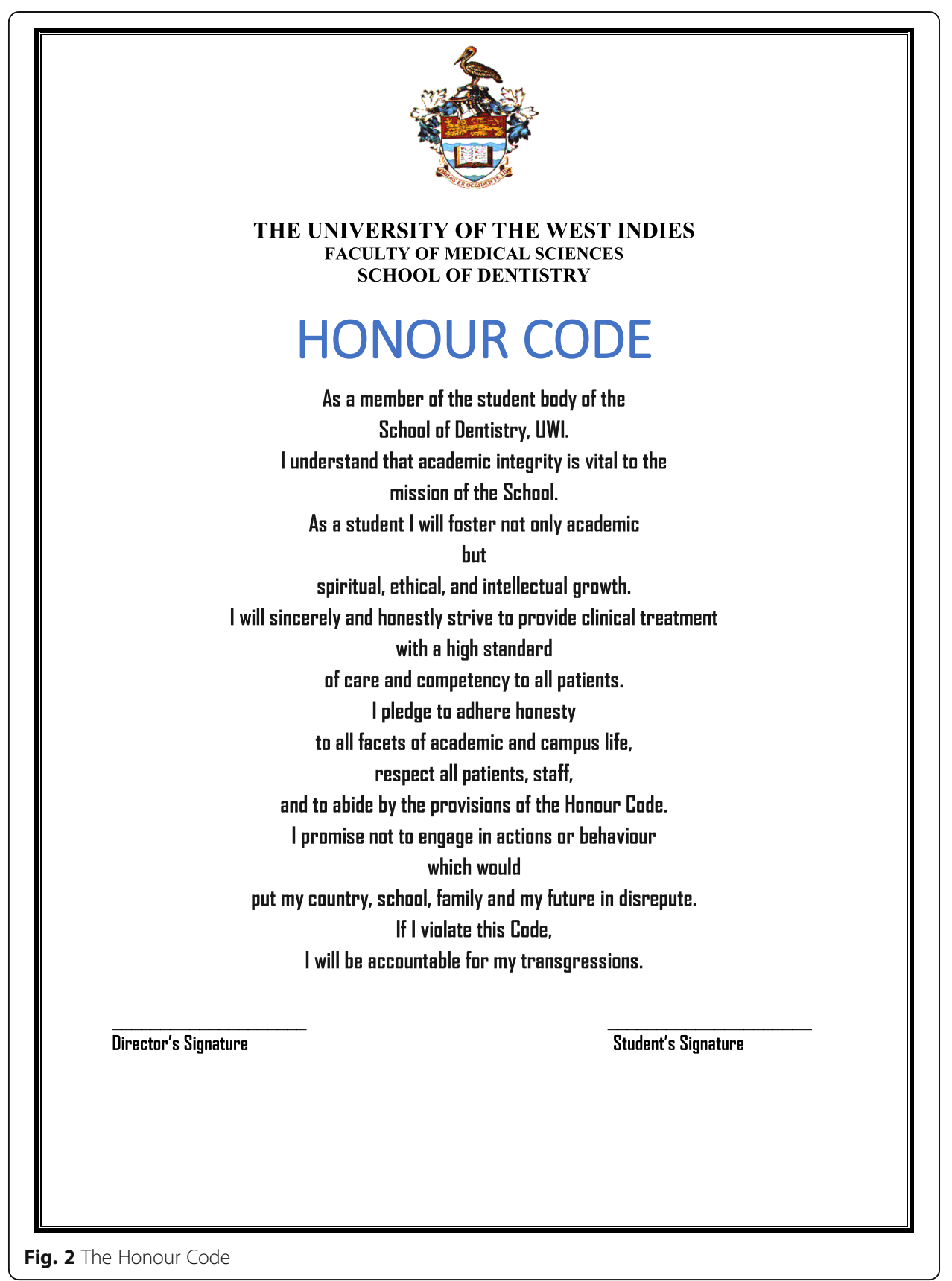

Introduce and identify the core biomedical principles of ethics and professionalism 3. Present an approach to making reasoned decision in the face of an ethical dilemma.

Semi-structured personal interviews of students were conducted for feedback and analysis. Researcher observations and student reflections on the honour code were also documented for analysis.

\section{Analysis of the data}

A mixed method approach was used to synthesize and analyze both forms of quantitative and qualitative data. Likert scale responses were converted into numerical scores 


\begin{tabular}{|c|c|c|c|c|c|c|}
\hline & Questions & 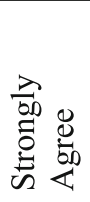 & 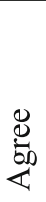 & 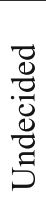 & 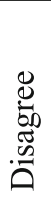 & 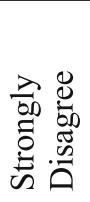 \\
\hline 1 & The Honour Code is of relevance to students & 1 & 2 & 3 & 4 & 5 \\
\hline 2 & $\begin{array}{l}\text { The Honour Code reminds me that I should } \\
\text { be honest in my actions on clinic }\end{array}$ & 1 & 2 & 3 & 4 & 5 \\
\hline 3 & $\begin{array}{l}\text { The Honour Code reminds me that I need to } \\
\text { be fair in actions }\end{array}$ & 1 & 2 & 3 & 4 & 5 \\
\hline 4 & $\begin{array}{l}\text { The Honour Code reminds me that I to } \\
\text { respect all staff and patients in my clinical } \\
\text { environment }\end{array}$ & 1 & 2 & 3 & 4 & 5 \\
\hline 5 & $\begin{array}{l}\text { The Honour Code reminds me that I need to } \\
\text { be responsible in all my actions }\end{array}$ & 1 & 2 & 3 & 4 & 5 \\
\hline 6 & $\begin{array}{l}\text { The Honour Code reminds me that I need to } \\
\text { be trustworthy in all my actions }\end{array}$ & 1 & 2 & 3 & 4 & 5 \\
\hline 7 & $\begin{array}{l}\text { The Honour Code should be implemented } \\
\text { annually in third year }\end{array}$ & 1 & 2 & 3 & 4 & 5 \\
\hline 8 & $\begin{array}{l}\text { The School of Dentistry needs to do more to } \\
\text { encourage academic integrity }\end{array}$ & 1 & 2 & 3 & 4 & 5 \\
\hline
\end{tabular}

for each pre- and post- intervention questionnaire item. Quantitative analyses included distribution frequencies and statistical comparison (analysis of variance; ANOVA) of mean pre- and post- intervention questionnaire scores to determine if there was a change in students' perceptions after the sessions (IBM SPSS Statistics 24 statistical software, IBM Corporation, Armonk, New York, USA).

Qualitative data analysis was used to identify themes with fundamental and unifying concepts from the student experiences as a whole (Ryan and Bernard 2003; Bradley et al. 2007). A process of data source triangulation by interviews, reflections and observations and questionnaire were conducted to determine any overall emergent themes (Fig. 5) (Carter et al. 2014). This triangulation process provided validity through data convergence from at least three sources (Patton 1999). Relationship and perspective coding among student data were used to elucidate the themes through an inductive process (Bradley et al. 2007). The actual process of coding involved open, axial and selective coding (Corbin and Strauss 2015). Open coding was applied to breakdown the raw data into broad emotive or attitudinal categories of positive, indifferent and oppositional attitude. Selective coding was used to establish core categories and axial coding to establish the relationships patterns and theme linkages. Both researchers independently coded and collaborated to derive consensus to ensure further validity to the process. 
Session I: Questionnaire on record keeping and confidentiality

Please circle answers below

\begin{tabular}{|c|c|c|c|c|c|c|}
\hline & Questions & 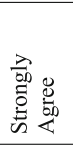 & 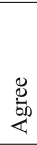 & 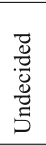 & 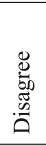 & 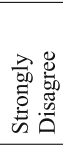 \\
\hline 1 & $\begin{array}{l}\text { Patients' files are my property as long as } \\
\text { the patients are under my care }\end{array}$ & 1 & 2 & 3 & 4 & 5 \\
\hline 2 & $\begin{array}{l}\text { I can remove/discard patient information } \\
\text { sheets from the files }\end{array}$ & 1 & 2 & 3 & 4 & 5 \\
\hline 3 & $\begin{array}{l}\text { I can use liquid paper to correct my } \\
\text { mistakes }\end{array}$ & 1 & 2 & 3 & 4 & 5 \\
\hline 4 & $\begin{array}{l}\text { I can take home my files once I bring it } \\
\text { back to the clinic the next day }\end{array}$ & 1 & 2 & 3 & 4 & 5 \\
\hline 5 & $\begin{array}{l}\text { My patients are honest and will inform } \\
\text { me of their medical history }\end{array}$ & 1 & 2 & 3 & 4 & 5 \\
\hline 6 & $\begin{array}{l}\text { I can share the information from my } \\
\text { patients files with my friends and family }\end{array}$ & 1 & 2 & 3 & 4 & 5 \\
\hline 7 & $\begin{array}{l}\text { If I make a mistake in my diagnosis and } \\
\text { treatment it does not matter as I am } \\
\text { learning }\end{array}$ & 1 & 2 & 3 & 4 & 5 \\
\hline 8 & $\begin{array}{l}\text { If the patient is irritating and problematic } \\
\text { I can indicate this in my file }\end{array}$ & 1 & 2 & 3 & 4 & 5 \\
\hline
\end{tabular}

Session II: Questionnaire on clinical scenarios

Please circle answers below

\begin{tabular}{|l|l|llll|}
\hline \multicolumn{1}{|c|}{ Questions } & & & & \\
\hline
\end{tabular}

Fig. 4 Sample questionnaire for clinical scenarios sessions 


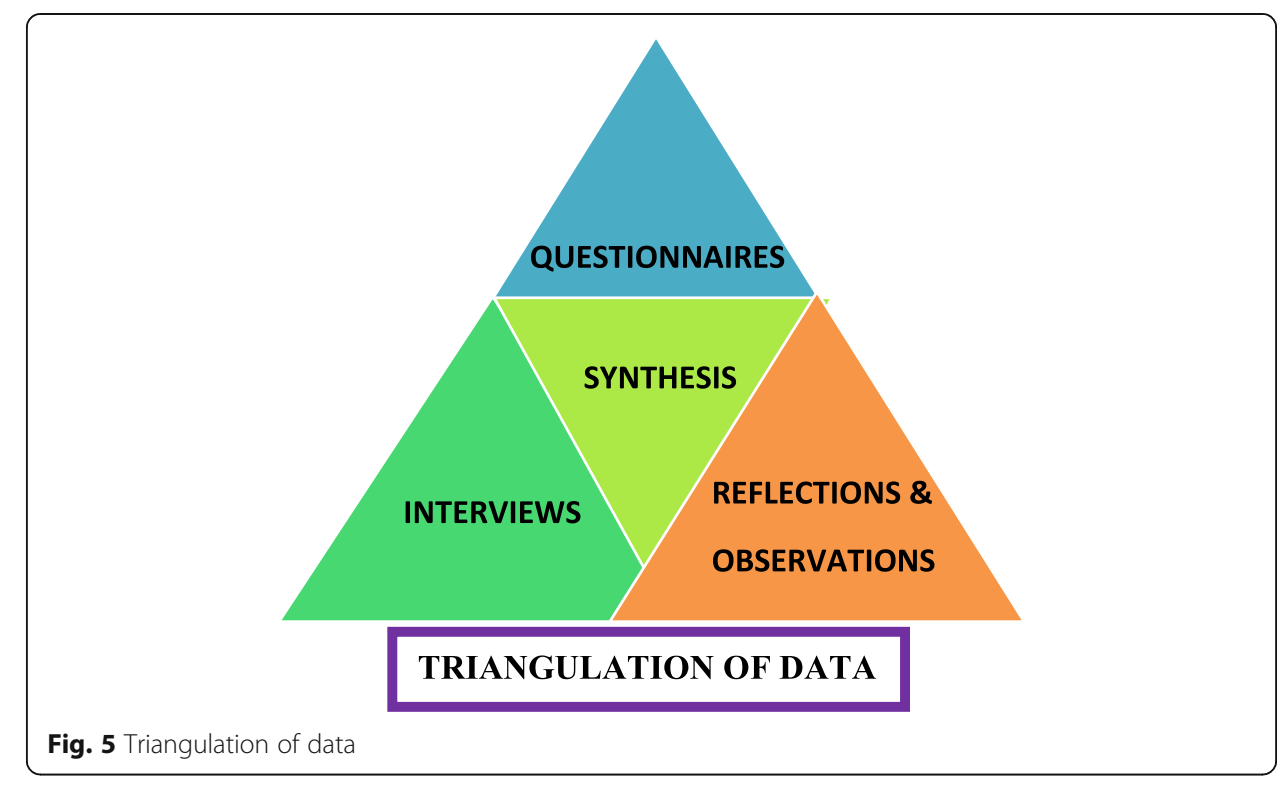

\section{Results}

Pre-study questionnaire on academic dishonesty

A total of 91 students (age: 20-34 years; gender: $71 \%$ female and 29\% male) consisting of 3rd, 4th and 5th year classes completed the pre-study questionnaire on academic dishonesty to identify the problem in this action research (Table 1). In response to the presence of dishonesty at the SOD, 71.7\% agreed while equal amounts disagreed or didn't know (14.1\%). High percentages of students participated or observed of their peers: forged signatures (66.3\%), plagiarism (44.5\%) and shared test $(40.2 \%)$ for non-clinical settings. In clinical settings, students participated or observed of their peers: falsified clinical notes $(28.3 \%)$ and discarded clinical notes (19.6\%).

Table 1 Pre-Study Questionnaire on Academic Dishonesty

\begin{tabular}{|c|c|c|c|c|c|c|}
\hline \multirow[t]{2}{*}{ Observed Items } & \multicolumn{2}{|c|}{ Yes } & \multicolumn{2}{|l|}{ No } & \multicolumn{2}{|c|}{ Don't Know } \\
\hline & $\mathbf{n}$ & $\%$ & $\mathbf{n}$ & $\%$ & $\mathbf{n}$ & $\%$ \\
\hline Dishonesty & 66 & 71.7 & 13 & 14.1 & 13 & 14.1 \\
\hline Forged signature & 61 & 66.3 & 29 & 31.5 & 2 & 2.2 \\
\hline Copied in written exam & 29 & 31.5 & 61 & 66.3 & 2 & 2.2 \\
\hline Use of disallowed material & 14 & 15.2 & 76 & 82.6 & 2 & 2.2 \\
\hline Ghost author & 14 & 15.2 & 76 & 82.6 & 2 & 2.2 \\
\hline Plagiarism & 41 & 44.5 & 49 & 53.3 & 2 & 2.2 \\
\hline Shared test & 37 & 40.2 & 53 & 57.6 & 2 & 2.2 \\
\hline Falsified clinical notes & 26 & 28.3 & 64 & 69.6 & 2 & 2.2 \\
\hline Discarded clinical notes & 18 & 19.6 & 72 & 78.3 & 2 & 2.2 \\
\hline Unnecessary clinical procedures & 7 & 7.6 & 83 & 90.2 & 2 & 2.2 \\
\hline Cheating in clinical exam & 5 & 5.4 & 85 & 92.4 & 2 & 2.2 \\
\hline False medical absenteeism & 4 & 4.3 & 86 & 93.5 & 2 & 2.2 \\
\hline
\end{tabular}


Introduction of the honour code

Post- honour code questionnaire

Population The total sample population comprised of 56 students of the 3rd year ( $n=$ $27)$ and 4 th year $(n=29)$ classes. The mean age was 24.1 years and the gender distribution was $69.6 \%(n=39)$ females and $30.4 \%(n=17)$ males. The 5 th year class was excluded as they were at the end of their clinics and would have developed various perceptions through their clinical training which would have biased this study approach of intervention at the start of clinics.

Table 2 showed the responses of students from the post-honour code questionnaire. The questionnaire response rates were $88.9 \%(n=24)$ for the 3rd and 93.1\% $(n=27)$ for the 4 th year students (overall total $n=51 ; 91.1 \%$ ). The relevance of the honour code was reported by $86.3 \%$ of students. Based on five ICAI fundamental original values, students agreed/strongly agreed that the honour code encouraged honesty (94.1\%), trust (92.2\%), fairness $(92.2 \%)$, respectfulness $(94.1 \%)$ and responsibility (96.1\%). Annual implementation of the honour code was reportedly agreed/strongly agreed by $86.3 \%$ of students. It was also agreed/strongly agreed that the SOD should encourage academic integrity by $82.4 \%$ of the students surveyed.

\section{Creative pedagogical strategies: clinical scenarios Session 1 (Record keeping and confidentiality).}

There was $87.5 \%$ participation based on attendance by the 3rd and 4th year students for the Clinical Scenario: session I $(n=49)$. The mean post-intervention values generally improved compared to the pre-intervention values for all questions (Table 3). Only the question on ability to take patient's notes home showed statistically significant difference (ANOVA; $p=0.016$ ) between the mean pre-intervention score (mean 3.8; standard deviation 1.1) and the mean post-intervention score (mean 4.3; standard deviation 0.9).

\section{Session 2 (Case related ethical issues).}

There was $87.5 \%$ participation based on attendance by the 3rd and 4th year students for the Clinical Scenario: session II $(n=49)$. Eleven out of the thirty-six questions showed statistically significant difference (ANOVA; $p<0.05$ ) between the mean pre-

Table 2 Post-Honour Code Questionnaire

\begin{tabular}{lll}
\hline Honour Code Questions & \multicolumn{2}{l}{ AGREED/STRONGLY AGREED } \\
\cline { 2 - 3 } & $\mathbf{n}$ & $\%$ \\
\hline Is Relevant & 44 & 86.3 \\
Encouraged Honesty & 48 & 94.1 \\
Encouraged Trust & 47 & 92.2 \\
Encouraged Fairness & 47 & 92.2 \\
Encouraged Respectfulness & 48 & 94.1 \\
Encouraged Responsibility & 49 & 96.1 \\
Implemented Annually & 44 & 86.3 \\
Academic Integrity should be encouraged & 42 & 82.4 \\
\hline
\end{tabular}


Table 3 Clinical scenarios I, pre- and post-intervention mean scores

\begin{tabular}{lllll}
\hline Clinical Scenario I (Record Keeping) & $\mathbf{n}$ & $\begin{array}{l}\text { Pre- Intervention } \\
\text { Mean (SD) }\end{array}$ & $\begin{array}{l}\text { Post- Intervention } \\
\text { Mean (SD) }\end{array}$ & Sig \\
\hline File is my property & 49 & $3.2(1.4)$ & $3.7(1.3)$ & 0.064 \\
Discard patient information & 49 & $4.6(0.5)$ & $4.6(0.5)$ & 0.544 \\
'Liquid paper' correction & 49 & $4.3(0.8)$ & $4.5(0.5)$ & 0.099 \\
Take files home & 49 & $3.8(1.1)$ & $4.3(0.9)$ & 0.016 \\
Honest medical history & 49 & $3.8(0.8)$ & $4.1(0.8)$ & 0.063 \\
Legally bound file information & 49 & $4.1(1.1)$ & $4.1(1.2)$ & 0.796 \\
Share information with family/friends & 49 & $4.5(0.8)$ & $4.7(0.5)$ & 0.369 \\
Diagnosis/treatment mistake & 49 & $3.3(1.1)$ & $2.9(1.1)$ & 0.067 \\
Irritating patient noted & 49 & $2.4(1.2)$ & $2.2(1.2)$ & 0.460 \\
\hline
\end{tabular}

intervention scores and the mean post-intervention scores as selectively shown in Table 4. The remaining twenty-five questions had improved mean post-intervention scores to pre-intervention scores but these failed to show statistical significance.

Qualitative analysis Personal student interviews were obtained from a sample of the Year III class after the pedagogical sessions on academic integrity. There was a participation rate of $72 \%$ (21 out of 29 students) as this activity was voluntary. Interviews for year IV students were not obtained as they had already started clinics and the focus was knowledge prior to the start of clinics.

The data collected for these 21 students included students' narrative reflections, researchers' observations, personal interviews and student comments after their clinical scenario sessions. An ad-hoc analysis of this data provided preliminary evidence that the majority ( $n=18 ; 85.7 \%)$ of students showed positive changes in perception and understanding of academic integrity.

Based on open coding, students' responses were categorized into three perceptive or attitudinal themes: positive, indifferent and oppositional. Further selective coding allowed for identification of unit words and phrases. Subthemes were derived based on

Table 4 Clinical scenarios II, pre- and post-intervention mean scores

\begin{tabular}{lllll}
\hline $\begin{array}{l}\text { Clinical Scenario II } \\
\text { (Case Specific) }\end{array}$ & $\mathbf{n}$ & $\begin{array}{l}\text { Pre-Intervention } \\
\text { Mean (SD) }\end{array}$ & $\begin{array}{l}\text { Post-Intervention } \\
\text { Mean (SD) }\end{array}$ & Sig \\
\hline Medically compromised; refer to hospital & 49 & $2.5(0.7)$ & $1.8(0.9)$ & 0.000 \\
Ulcer; refer to oral surgeon & 49 & $1.7(0.9)$ & $1.3(0.5)$ & 0.002 \\
RCT file broken; liable & 49 & $3.7(2.8)$ & $2.3(0.9)$ & 0.000 \\
Copy patient record; fee & 49 & $3.8(1.0)$ & $4.3(0.9)$ & 0.001 \\
Copy patient record; new dentist & 49 & $2.5(1.1)$ & $1.9(0.8)$ & 0.002 \\
Veneers; refuse \& opinion & 49 & $2.0(0.8)$ & $1.4(0.5)$ & 0.000 \\
Bridgework; 2nd opinion & 49 & $2.0(0.7)$ & $1.7(0.7)$ & 0.020 \\
Bridgework; disclaimer doesn't absolve & 49 & $2.5(1.0)$ & $2.1(0.9)$ & 0.017 \\
Gift; type/purpose of gift & 49 & $2.8(1.1)$ & $2.1(1.0)$ & 0.002 \\
Inappropriate contact; report to relevant body & 49 & $2.1(0.9)$ & $1.7(0.9)$ & 0.034 \\
Mistaken dental office; send \& claim you're better & 49 & $3.6(0.9)$ & $4.1(0.9)$ & 0.006 \\
\hline
\end{tabular}


these unit codes as tabulated under the respective theme heading (Table 5). The positive subthemes which emerged validated the five fundamental original values of the ICAI.

'Honesty' was based on tenets of goodness, to be true and integrity, 'trust' was based on faith in the practitioner, 'fairness' was based on justice, 'respectful' was based on pride and honour and 'responsibility' was based on obligation, duty and being the best professional. Some additional themes which emerged included 'revelation' which was a sort of an epiphany for many students, 'moral code' which was based on personal value system, good behaviour and guidance based on a pledge (honour code) and 'ethics and professionalism' which guided professional ethical behaviour. Other positive subthemes included the need for 'cooperation' through team work or collaboration and finally 'education' of all inclusive of non-clinical years and staff. Indifferent subthemes were infrequently reported as these individuals remained 'neutral' either due to lack of interest, lack of understanding or being unaffected by the efforts of this project. Finally, a smaller proportion of data lead to the oppositional subthemes of 'irrelevant' or 'recalcitrant' attitude.

\section{Discussion}

The implementation of the honour code did engender positive perceptions of academic integrity. Students reported that the honour code was a relevant strategy (86.3\%) which encouraged the five investigated fundamental values of the ICAI on academic integrity (>92\%) and should be implemented annually (86.3\%) based on the post- honour code questionnaire. They also viewed that the honour code was a personal pledge which encouraged professionalism and ethics as well as honesty and responsibility stemming out of the personal interviews. The students developed a non-punitive but accountable honour code which focused on trust, integrity, respect and holistic educational growth of the student as has been advocated by Tatum and Schwartz (2017).

The sixth fundamental value of 'Courage' was excluded from the post- honour code questionnaire as it was a quality element for commitment to action rather than an original value. It was difficult for students to ascertain this attribute at the start of clinics as they lacked this experience and thus had little insight into this moral fortitude. The qualitative analysis also failed to reveal this sixth fundamental value possibly due to lack of experience.

The findings from the pre-study confirmed the problem of academic dishonesty with a high percentage of $71.7 \%$ which was comparable to that reported in the literature for other dental schools (Andrews et al. 2007; Choi 2019) and for other academic fields within Trinidad (De Lisle et al. 2011). In our study, some students reported collusion (shared test) as observed academic dishonesty and De Lisle et al. (2011) also noted that students were uncertain as to this being academic dishonesty. The high percentages of academic dishonesty also necessitated this action research with both implementations of the honour code and academic integrity pedagogical strategies.

The creative pedagogical strategies were insightful as to the shared ideas of the students in the various clinical scenarios. Many of the questions which failed to show changes statistically were a reflection of only small changes from pre-intervention to post-intervention score but more importantly already established ethical and professional concepts which are an innate part of the students' moral ideologies. As an 
Table 5 Themes, subthemes, codes and student responses

\begin{tabular}{|c|c|c|}
\hline \multicolumn{3}{|c|}{ Theme: POSITIVE ATTITUDE } \\
\hline Subtheme & $\begin{array}{l}\text { Coding } \\
\text { Word/Phrase }\end{array}$ & Sample Student Responses \\
\hline Honesty & $\begin{array}{l}\text { Goodness } \\
\text { True } \\
\text { Integrity }\end{array}$ & $\begin{array}{l}\text { These sessions have made me want to be honest and true and give } \\
\text { future patients all the required treatment needed to help maintain in } \\
\text { practice good oral hygiene and not cause then any harm. } \\
\text { To not do any mischief. } \\
\text { Honesty is a big part of the Honour Code. } \\
\text { Integrity as a person. }\end{array}$ \\
\hline Trust & Faith & $\begin{array}{l}\text { It allows me to realize that these patients are human being like me and } \\
\text { that they place a lot of trust in you the clinician to treat them. }\end{array}$ \\
\hline Fairness & Justice & $\begin{array}{l}\text { Most of us assume that we know right from wrong and this is probably } \\
\text { true in most cases however there are some instances when right and } \\
\text { wrong are not so clearly differentiated. }\end{array}$ \\
\hline Respectful & $\begin{array}{l}\text { Pride } \\
\text { Honour }\end{array}$ & $\begin{array}{l}\text { These sessions mould me into the type of dentist that I truly hope I } \\
\text { become } 1 \text { day. A dentist who has a respectful and honest character. } \\
\text { Sets pride for you within your profession }\end{array}$ \\
\hline Responsibility & $\begin{array}{l}\text { Obligation } \\
\text { Duty } \\
\text { Professional }\end{array}$ & $\begin{array}{l}\text { The scenarios put for today really guided my thoughts down the right } \\
\text { path. } \\
\text { It is my duty to help educate and treat then accordingly. } \\
\text { It helps inform someone who is new and now entering into the clinic } \\
\text { the different guidelines they need to follow. } \\
\text { It is a big step. } \\
\text { It is necessary. } \\
\text { Something to follow. } \\
\text { To be the best professional } \\
\text { A form of responsibility } \\
\text { Something to stand by. } \\
\text { It is a promise you make every day. }\end{array}$ \\
\hline Revelation & $\begin{array}{l}\text { Reflective } \\
\text { Epiphany }\end{array}$ & $\begin{array}{l}\text { It did expose me to situations that I didn't put much thought into on } \\
\text { how to solve effectively. } \\
\text { The class brought situations to life and some of my opinions changed. } \\
\text { It is an eyeopener. } \\
\text { On your toes. } \\
\text { Just makes me more vigilant about certain situations. }\end{array}$ \\
\hline Moral Code & $\begin{array}{l}\text { Promise } \\
\text { Good behaviour } \\
\text { Guidance }\end{array}$ & $\begin{array}{l}\text { We were told that there were no "black" and "white" answers to } \\
\text { questions. The answer was really up to the individual and their beliefs } \\
\text { and values. } \\
\text { It is very personal } \\
\text { It is a signed contract. } \\
\text { Pledge to live by. } \\
\text { It establishes the standard to adhere to. } \\
\text { Conduct yourself in a manner that is needed. } \\
\text { To find solutions and to obtain help and advice for particular scenarios. } \\
\text { If faced with one of the scenarios discussed in the questionnaire we can } \\
\text { now follow it. }\end{array}$ \\
\hline Cooperation & Collaboration & It encourages student team work \\
\hline $\begin{array}{l}\text { Ethics and } \\
\text { Professionalism }\end{array}$ & Ethics & $\begin{array}{l}\text { I was able to have a better understanding on certain ethical issues that } \\
\text { a professional may face. } \\
\text { I believe it is important to have exercise such as this one where students } \\
\text { are given different ethical dilemmas as it provided the opportunity for } \\
\text { misconceptions or wrong ideas to be corrected. } \\
\text { The ethical sessions were helpful such that it cleared up some issues we } \\
\text { could possibly face in our profession (that we never really thought } \\
\text { about). } \\
\text { Stressed the ethical behaviour in clinic }\end{array}$ \\
\hline Education & Inclusion & $\begin{array}{l}\text { I recommend that the lower years have such sessions. } \\
\text { I would recommend even further sessions as my year group progresses } \\
\text { and meet new challenges. } \\
\text { Staff and support staff should also have to abide by one. } \\
\text { A bigger venue is needed for ceremony. }\end{array}$ \\
\hline
\end{tabular}


Table 5 Themes, subthemes, codes and student responses (Continued)

\begin{tabular}{|c|c|c|}
\hline \multicolumn{3}{|c|}{ Theme: INDIFFERENT ATTITUDE } \\
\hline Subtheme & $\begin{array}{l}\text { Coding } \\
\text { Word/Phrase }\end{array}$ & Sample Student Responses \\
\hline Neutral & $\begin{array}{l}\text { Undecided } \\
\text { No change }\end{array}$ & $\begin{array}{l}\text { I am undecided on the concept of the Honour Code. } \\
\text { The class has not really changed my outlook or clinical procedures. }\end{array}$ \\
\hline \multicolumn{3}{|c|}{ Theme: OPPOSITIONAL ATTITUDE } \\
\hline Subtheme & $\begin{array}{l}\text { Coding } \\
\text { Word/Phrase }\end{array}$ & Sample Student Responses \\
\hline Irrelevant & $\begin{array}{l}\text { Not beneficial } \\
\text { Not curriculum }\end{array}$ & $\begin{array}{l}\text { The past sessions has proven to not be beneficial as it is very difficult to } \\
\text { wake up at } 5: 00 \text { am in the morning and stay nearly } 2 \mathrm{~h} \text { in traffic for a } \\
\text { class that does not pertain to the curriculum. } \\
\text { The past sessions does not pertain to the curriculum. } \\
\text { It does not pertain to dentistry. }\end{array}$ \\
\hline Recalcitrant & $\begin{array}{l}\text { Disinterested } \\
\text { Aloof }\end{array}$ & $\begin{array}{l}\text { I know everything already. I don't need these sessions. } \\
\text { Total waste of my time. } \\
\text { Sessions too early. }\end{array}$ \\
\hline
\end{tabular}

example, students' perception that alteration of patient files with correction fluid ('Liquid Paper') was unacceptable was correctly reportedly high at both pre-intervention and post-intervention. Conversely, students' concept that files may be taken home was wrongly identified in higher numbers by students at pre-intervention compared to post-intervention. This recognized problem within clinics where files are missing or not available on the day of treatment clearly presents an ethical and professional dilemma for patient management. Overall, students did show an improvement in ideas as related to the clinical scenarios and academic integrity. Additionally, students indicated a need for continued support and education through this creative pedagogical interaction.

The qualitative analyses of data from the interviews, questionnaires, reflections and observations revealed themes related to the students' interpretation and understanding of the honour code and academic integrity. This improved perception of moral and professional duty may have defined the framework for interpretation of the clinical scenario cases as a whole. However, it was difficult to relate such an understanding to individual cases as the cases were developed to cover common clinical ethical items which were observed in the UWI SOD. There was no prior purpose to validate the clinical scenario questionnaire as this was simply used as an educational tool for achieving gains in the overall concept of academic integrity.

As $85.7 \%$ of students reported some gain in perception and knowledge of academic integrity, it was not unexpected that the majority of students' narratives/responses were positive and the emerging subthemes also espoused the five investigated fundamental values of academic integrity. Students also reported a revelation or epiphany moment as to the value of both the sessions of academic integrity and the honour code. There was also reinforcement and development of ideas on ethical and professionalism and the need for cooperation and team work.

Students who had difficulties with the sessions were generally indifferent and opposed to these sessions outside the visible curriculum despite the sessions being conducted during regular school hours. Very few were opposed or displayed an aloof or recalcitrant attitude. One oppositional response stemmed out of a personal challenge in transportation to the SOD. 
Whipp et al. (2000) stated that emancipatory and practical knowledge are critical components, as it emphasizes group problem solving behaviour, ethical reflection and ethical examination. Graham et al. (2016) also reported that most universities used a case-based approach to ethics education. This SOD study supports these creative pedagogical group strategies utilized in the educational sessions on academic integrity.

Although there was change in students' perception, we cannot validate whether students retained, habituated or acted on this knowledge. No doubt these short sessions are steps towards encouraging academic integrity and do not contend that there will be subsequent behaviour change. Nevertheless, students have taken a pledge for their future and these sessions hopefully would have evoked some innate positive awareness. Main insights derived from the study included additional educational support for integration of the honour code and academic integrity with the curriculum and the necessity for inclusion of staff who should also be compliant with academic integrity. Out of 61 US accredited Dental Schools, only 59\% reported statements addressing expected faculty academic behaviours (Graham et al. 2016). Students pattern and learn from their mentors so it is imperative that good example is established and maintained by staff.

Measure such as guidebooks, policies and a student honour code regulatory body are all needed for proper guidance and regulation. Ethics, professionalism and encouraging academic integrity are a multipronged process within the institution. Collaboration and discussion with faculty staff, student body, previous alumni and regional or international institutions or groups may be needed for this process.

\section{Conclusion}

In summary, the implementation of an honour code coupled with creative pedagogical strategies helped to foster understanding and appreciation for academic integrity. Conversely the honour code implementation may have been more effective due to the combination with creative pedagogical strategies on academic integrity. Further, creative pedagogical strategies with interactive and introspective sessions using clinical scenarios are needed for greater understanding by students and its application to clinical practice. The honour code, policy guidelines and students' honour code regulatory body are needed if universities are serious in encouraging academic integrity. The hidden curriculum of academic integrity should be emphasised in dental education for a more holistic training. Inclusion of staff and their commitment to academic integrity fosters ethics among students through staff example. A future long-term study on academic integrity following students' change in behaviour and practice during clinical training and post-graduation may be useful.

\footnotetext{
Abbreviations

ICAI: The International Centre of Academic Integrity; SOD: School of Dentistry; UWI: University of the West Indies; ANOVA: Analysis of Variance; IBM : International Business Machines; SPSS: Statistical Product and Service Solutions; n: Number; SD: Standard Deviation; Sig: Significance; p: Probability; AR: Action Research; US: United States; USA: United States of America; UK: United Kingdom
}

Acknowledgements

Dr. Dianne Thurab Nkhosi for guidance and supervision of this research project and MHEd. 


\section{Authors' information}

VR is a lecturer in Periodontology teaching undergraduate dental students and in the past dental hygiene and therapy students at the School of Dentistry, The University of the West Indies. She obtained her DDS (Doctor of Dental Surgery) at the University of the West Indies, Trinidad; DPDS (Diploma in Postgraduate Dental Studies) at the University of Bristol, UK; MScD (Master of Science in Dentistry) with research in Periodontology from the Cardiff University, UK and MHEd (Master in Higher Education) at the University of the West Indies. Prior to lecturing at the University of the West Indies, VR was a Senior House Officer at Cardiff University where she also engaged in supporting undergraduate dental education. VR has helped develop the teaching and clinical training within Periodontology at the School of Dentistry, The University of the West Indies.

SR is the lead lecturer in Periodontology teaching undergraduate dental students and in the past dental hygiene and therapy students at the School of Dentistry, The University of the West Indies for over 18 years. He obtained his DDS (Doctor of Dental Surgery) at the University of the West Indies Trinidad; MSc (Master of Science) in Periodontology and MClinDent (Master of Clinical Dentistry) in Periodontology from the Eastman Dental Institute, University College London and MFDS RCSEd (Member of the Faculty of Dental Surgery) at the Royal College of Surgeons, Edinburgh. SR has also completed a Certificate in Undergraduate Teaching and Learning (CUTL). As the lead lecturer, SR has been responsible for developing the blended curriculum inclusive of the online Moodle platform, MyeLearning in Periodontology.

\section{Funding}

The School of Dentistry, The University of the West Indies supported the teaching activities and the 'Honour Code' oath ceremony as part of the regular educational activities. There was no specific grant, award or budget.

\section{Availability of data and materials}

In maintaining the confidentiality clause of the students the data set is unpublished However, the data set used and/ or analysed during the current study are available from the corresponding author at her discretion on a reasonable request.

\section{Competing interests}

All authors are lecturers at the School of Dentistry, The University of the West Indies, St Augustine, Trinidad. This paper was based on the research project as part criteria for fulfillment of MHEd (Master in Higher Education) at The University of the West Indies by Dr. Vidya Raman.

Received: 13 February 2020 Accepted: 5 October 2020

Published online: 11 November 2020

\section{References}

Ackerman SL, Boscardin C, Karliner L, Handley MA, Cheng S, Gaither TW, Hagey J, Hennein L, Malik F, Shaw B, Trinidad N, Zahner G, Gonzales R (2016) The action research program: experiential learning in systems-based practice for first-year medical students. Teach Learn Med 28(2):183-191

Al-Dwairi ZN, Al-Waheidi EM (2004) Cheating behaviours of dental students. J Dent Educ 68(11):1192-1195

Aleinikov A (2013) Creative pedagogy. Encyclopedia of creativity, invention, innovation, and entrepreneurship. Springer, New York, p 327

Andrews KG, Smith LA, Henzi D, Demps E (2007) Faculty and student perceptions of academic integrity at U.S. and Canadian dental schools. J Dent Educ 71(8):1027-1039

Beemsterboer PL, Odom JG, Pate TD, Haden NK (2000) Issues of academic integrity in U.S. dental schools. J Dent Educ 64(12): $833-838$

Berk NW (2001) Teaching ethics in dental schools: trends, techniques, and targets. J Dent Edu 65(8):744-750

Bertolami CN (2004) Why our ethics curricula don't work. J Dent Educ 68:414-425

Bradley EH, Curry LA, Devers KJ (2007) Qualitative data analysis for health services research: developing taxonomy, themes, and theory. Health Serv Res 42(4):1758-1772

Bretag T, Harper R, Burton M, Ellis C, Newton P, Saddiqui S, Rozenberg P, van Haeringen K (2019) Contract cheating: a survey of Australian university students. Stud High Educ 44(11):1837-1856

Bretag T, Mahmud S, Wallace M, Walker R, McGowan U, East J, Green M, Partridge L, James C (2013) 'Teach us how to do it properly!' An Australian academic integrity student survey. Stud High Educ 39(7):1150-1169

Carpenter DD, Harding TS, Finelli CJ, Passow HJ (2004) Does academic dishonesty relate to unethical behavior in professional practice? An exploratory study. Sci Eng Ethics 10(2):311-324

Carter N, Bryant-Lukosius D, DiCenso A, Blythe J, Neville AJ (2014) The use of triangulation in qualitative research. Oncol Nurs Forum 41(5):545-547

Choi J (2019) Cheating behaviors and related factors at a Korean dental school. Korean. J Med Educ 31(3):239-249

Corbin J, Strauss A (2015) Basics of qualitative research. Sage, Thousand Oaks

Currie W, Dracopoulos S, Hendry G (2017) Cheating in a dental practical exam. Int J Educ Integr 13:5 https://doi.org/10.1007/ s40979-017-0017-2

De Lisle J, Hyland-Joseph S, Bowrin-Williams C (2011) "A little leaven corrupteth the whole lump": academic cheating as a hindrance to achieving quality in higher education. Caribb Teach Scholar 1(1):5-19

Dix EL, Emery LF, Le B (2014) Committed to the honor code: an investment model analysis of academic integrity. Soc Psychol Educ 17:179-196

Elander J, Pittam G, Lusher J, Fox P, Payne N (2010) Evaluation of an intervention to help students avoid unintentional plagiarism by improving their authorial identity. Assess Eval High Edu 23(2):157-171

Engler JN, Landau JD, Epstein M (2008) Keeping up with the joneses: students perceptions of academically dishonest behaviour. Teach Psychol 35(2):99-102 
Erlam G, Smythe L, Wright-St Clair V (2018) Action research and millennials: improving pedagogical approaches to encourage critical thinking. Nurse Educ Today 61:140-145

Fishman T (Editor) (2014) The fundamental values of academic integrity. $2^{\text {nd }}$ Edition. International Center for Academic Integrity (ICAI). Clemson University, South Carolina. At: https://www.academicintegrity.org/wp-content/uploads/2017/12/ Fundamental-Values-2014.pdf Accessed: June $18^{\text {th }} 2020$

Forna A (2012) Opinion students: will a student lie, cheat, steal, or tolerate those who do? The Guardian. At:https:/www. theguardian.com/commentisfree/2012/may/20/us-universities-honour-code-exams Accessed 15 Sept 2020

Gabbay DS (1999) A medical student honor code. Emerg Med Clin North Am 17(2):417-428

Gibbs P, Cartney P, Wilkinson K, Parkinson J, Cunningham S, James-Reynolds C, Zoubir T, Brown V, Barter P, Sumner P, MacDonald A, Dayananda A, Pitt A (2017) Literature review on the use of action research in higher education. Educ Action Res 25(1):3-22

Graham BS, Knight GW, Graham L (2016) Dental student academic integrity in U.S. dental schools: current status and recommendations for enhancement. J Dent Educ 80(1):5-13

Gurung RAR, Wilhelm TM, Filz T (2012) Optimizing honor codes for online exam administration. Ethics Behav 22(2):158-162

Henson KT (1996) Teachers as researchers. Handbook of research on teacher education. J. Sikula, T. Buttery, and E. Guyton (Eds.) 2nd ed., pp. 53-64. New York: Macmillan. Washington, DC: American Educational Research Association

Humber College (2019) The School of Health Sciences, Academic Integrity Council At: https://healthsciences.humber.ca/ current-students/academic-integrity.html Resource video: https://www.youtube.com/watch?v=DycmxNbrRlk\#action= share Accessed 5 June 2019

Hutton PA (2006) Understanding student cheating and what educators can do about it. College Teach 54(1):171-176

Johnson AP (2012) A short guide to action research, Minnesota State University, Mankato, Pearson 4th edition

Karp S (2009) Teaching ethics and professionalism to dental students. Oral Health 99:15-23

Keener TA, Galvez Peralta M, Smith M, Swager L, Ingles J, Wen S, Barbier M (2019) Student and faculty perceptions: appropriate consequences of lapses in academic integrity in health sciences education. BMC Med Educ 19(1):209

Lewin K (1946) Action research and minority problems. In: Lewin GW (ed) Resolving social conflicts. Harper and Row, New York, p 148

Macfarlane B, Zhang J, Pun A (2014) Academic integrity: a review of the literature. Stud High Educ 39(2):339-358.

Marshall LL, Varnon AW (2017) Attack on academic dishonesty: what "lies" ahead? J Acad Adm High Educ 13(2):31-40

Martin DE, Rao A, Sloan LR (2009) Plagiarism, integrity, and workplace deviance: a criterion study. Ethics Behav 19(1):36-50

McCabe DL, Treviño LK (1993) Academic dishonesty: honor codes and other contextual influences. J High Educ 64(5):522-538

McCabe DL, Treviño LK, Butterfield KD (2001) Dishonesty in academic environments: the influence of peer reporting requirements. J High Educ 72(1):29-45

McCabe DL, Treviño LK, Butterfield KD (2002) Honor codes and other contextual influences on academic integrity: a replication and extension to modified honor code settings. Res High Educ 43(3):357-378

Melendez B (1985) Honor code study. Harvard University, Cambridge

Miller A, Shoptaugh C, Wooldridge J (2011) Reasons not to cheat, academic-integrity responsibility, and frequency of cheating. J Exp Educ 79(2):169-184

Muhney KA, Gutmann ME, Schneiderman E, DeWald JP, McCann A, Campbell PR (2008) The prevalence of academic dishonesty in Texas dental hygiene programs. J Dent Educ 72(11):1247-1260

Naghdipour B, Emeagwali OL (2013) Students' justifications for academic dishonesty: call for action. Procedia Soc Behav Sci 83:261-265

Patton MQ (1999) Enhancing the quality and credibility of qualitative analysis. HSR: Health Serv Res. 34(5) II:1189-1208

Rennie SC, Crosby JR (2001) Are "tomorrow's doctors" honest? Questionnaire study exploring medical student's attitudes and reported behaviour on academic misconduct. BMJ. 322(7281):274-275

Robinson D, Schaap BM, Avoseh M (2018) Emerging themes in creative higher education pedagogy. J Appl Res Higher Educ 10(3):271-282

Ryan GW, Bernard HR (2003) Techniques to identify themes. Field Methods 15(1):85-109

Sagor R (2000) Guiding school improvement with action research. First ed. ASCD, VA, USA

Schwartz B, Tatum H, Hageman M (2013) College students' perceptions of and responses to academic dishonesty: the impact of honor codes. Ethics Behav 23(6):463-476

Shepherd J (2007) Higher education: an idea worth imitating. The Guardian. At:https:/www.theguardian.com/education/2 007/mar/20/highereducation.students. Accessed 15 Sept 2020

Spence M (2015) Academic honesty in coursework policy 2015. The University of Sydney. At:http://sydney.edu.au/policies/ showdoc.aspx?recnum=PDOC2012/254\&RendNum=0. Accessed 15 Sept 2020

Stoesz BM, Yudintseva A (2018) Effectiveness of tutorials for promoting educational integrity: a synthesis paper. BMC Int J Educ Integrity 14:6 https://doi.org/10.1007/s40979-018-0030-0

Tatum H, Schwartz BM (2017) Honor codes: evidence based strategies for improving academic integrity. Theory Pract 56(2):129-135

Thomas A, De Bruin G (2012) Student academic dishonesty: what do academics think and do and what are the barriers to action? Afr J Bus Ethics 6(1):13-24

University of Toronto (2019) Code of behaviour on academic matters. University of Toronto governing council. At: https:// governingcouncil.utoronto.ca/sites/default/files/2020-03/Code\%20of\%20Behaviour\%20on\%20Academic\%20Matters\%2 OJuly\%201\%202019.pdf. Accessed 15 Sept 2020

von Pressentin KB, Waggie F, Conradie H (2016) Towards tailored teaching: using participatory action research to enhance the learning experience of longitudinal integrated clerkship students in a south African rural district hospital. BMC Med Educ. 16:82. https://doi.org/10.1186/s12909-016-0607-3

Whipp JL, Ferguson DJ, Wells LM, lacopino AM (2000) Rethinking knowledge and pedagogy in dental education. J Dent Educ 64(12):860-866

Whitley B, Keith-Spiegel P (2002) Academic dishonesty: an educator guide. Psychology Press, New York

\section{Publisher's Note}

Springer Nature remains neutral with regard to jurisdictional claims in published maps and institutional affiliations. 